\title{
Use of Zeolite to Reduce the Bioavailability of Heavy Metals in a Contaminated Soil
}

\author{
Muhammad Moeen', Tian Qi' ', Zawar Hussain', Qilong Ge', Zahid Maqbool², \\ Xu Jianjie', Feng Kaiqing ${ }^{1}$ \\ ${ }^{1}$ College of Environmental Science and Engineering, Taiyuan University of Technology, 79 Yingze West Street, \\ Wanbailin District, Taiyuan, Shanxi, China \\ 2 Department of Environmental Sciences \& Engineering, Government College University, Faisalabad, Pakistan \\ * Corresponding author's e-mail: tqtyut@163.com, 412559908@qq.com
}

\begin{abstract}
Soil enrichment with heavy metals plays a significant role in soil pollution, which leads towards buildup/accumulation of heavy metals in edible crops. This situation causes severe threats to the sustainability of ecosystem and human health. The bioavailability of heavy metals can be restricted by the addition of immobilizing agents. Therefore, a pot experiment was carried out to evaluate the potential of zeolite i.e., 'clinoptilolite' as immobilizing agent to reduce the bioavailability of different heavy metals in soil. For this purpose, the pots containing soil contaminated with different heavy metals $(\mathrm{Cd}, \mathrm{Pb}, \mathrm{Cu}$ and $\mathrm{Zn})$ were treated with variable concentration of zeolite i.e., $1,3,5,7,9,15,20,30,40,50 \mathrm{~g} \cdot \mathrm{kg}^{-1}$, as well as the pots with no addition of ZL as control treatment and incubated for 30,60 and 90 days. The effectiveness of the applied treatments was evaluated by single metal extraction method in soil using DTPA having $7.3 \mathrm{pH}$ and $\mathrm{NH}_{4} \mathrm{NO}_{3}$. The results showed that the soils treated with ZL exhibited significant increases in soil $\mathrm{pH}$ and cation exchange capacity as well as a reduction in the concentration of metals $(\mathrm{Cd}, \mathrm{Pb}, \mathrm{Cu}$ and $\mathrm{Zn})$ as compared to the control soil. Among the different concentrations of $\mathrm{ZL}$, the most promising results were achieved with ZL at $50 \mathrm{~g} \cdot \mathrm{kg}^{-1}$ after 90 days of incubation. It was observed that the soil treated with zeolite at $50 \mathrm{~g} \cdot \mathrm{kg}^{-1}$ showed significantly higher contents of immobilized DTPA and $\mathrm{NH}_{4} \mathrm{NO}_{3}$ concentrations of Cd, $\mathrm{Cu}, \mathrm{Pb}$ and $\mathrm{Zn}$ after 90 days of incubation when compared with the control treatment. The trend of reduction in DTPA extractable concentration of heavy metals was in order of $\mathrm{Cd}<\mathrm{Pb}<\mathrm{Zn}<\mathrm{Cu}$ with reduction in contents up to $5.51,23.15,28.41$ and $35.66 \%$ respectively. In turn, the reduction of content for $\mathrm{Cd}, \mathrm{Cu}, \mathrm{Pb}$ and $\mathrm{Zn}$ by using $\mathrm{NH}_{4} \mathrm{NO}_{3}$ was as follows $16.09,20.11,23.83$ and $38.37 \%$, respectively, but the trend of reduction was $\mathrm{Cd}<\mathrm{Pb}<$ $\mathrm{Zn}<\mathrm{Cu}$. Therefore, reduction in concentration of heavy metals and their accumulation in the soil improved the soil quality. Hence, the addition of zeolites can significantly reduce the concentration of heavy metals in the soil although the reduction contents are not satisfactory for the production of food.
\end{abstract}

Keywords: immobilization, zeolite, DTPA, $\mathrm{NH}_{4} \mathrm{NO}_{3}$, heavy metals

\section{INTRODUCTION}

The pollution of soil with heavy metals has become a severe problem worldwide (Aryal et al., 2016; Houben et al., 2013; Luo et al., 2011; Sultana et al., 2014). Human activities, including industrial processes and production operations, smelting and mining, automobile exhaust led towards the accumulation of heavy metals in soil at the level that threatens the ecosystem services
(Cheung and Gu, 2007; Jackson et al., 2009; Kumar et al., 2012; Zhou et al., 2016). For agricultural soils, irrigation with the untreated wastewater discharged by mining activities is a common source of heavy metals pollution worldwide (Kumpiene et al., 2008). Moreover, the addition of animal manure compost and municipal solid waste compost in soil are the sources of heavy metal pollution, because these organic inputs contain large amounts of heavy metals (Toth et al., 
2016: Kumar et al., 2013). Among the numerous heavy metals, the concentration of $\mathrm{Cd}$ and $\mathrm{Cu}$ is much higher in municipal solid waste compost and livestock manure (Ayari et al., 2011).

Due to the accumulating nature of heavy metals, there is an increasing interest linked with the heavy metals contaminated soils and their proximate impacts on the global agricultural production system along with the food chain (Bian et al., 2014; Derakhshan Nejad et al., 2018). Ultimately now, it is a great challenge for researchers to introduce effective measuring techniques for the reduction of heavy metals bioavailability in soil. In order to minimize heavy metal contamination risk, many researchers have tested various soil remediation techniques and some of them has attached much attention worldwide (Liu et al., 2018). There are at least two ways to recover the heavy metals contaminated soil. The first way is to change the chemical state of these metals in the soil to their mobility, bioavailability and reduce the environmental risks by stabilizing heavy metals. The other way is to remove the heavy metals from the soil and bring them in the soil close or equal to the soil background (Wauna and Okieimen, 2011). Although, the immobilization of the heavy metals does not remove them from soil, it can effectively reduce the risks associated with heavy metals regarding plant intake, water pollution and soil biological exposure (Liu et al., 2018).

Previously, several researchers have used different amendments such as biochar, lime materials, steel slag, fly ash (FA) and zeolite (ZL) as cost effective technologies for the immobilization of heavy metals due to their chemical stabilization ability (Shaheen et al., 2014: Bolan et al., 2014). Among these amendments, zeolite (ZL) is a typical mineral modification that has been successfully used to remediate the heavy metals contaminated soils (Borowski and wasag, 2019). Because of its more surface area, high affinity for heavy metals and high alkalinity which enhances the fertility of soil and ultimately improves $\mathrm{pH}$, cation exchange capacity (CEC) and the water holding capacity (WHC) of the soil (Wang et al., 2016).

Zeolites are micrporous, crystalline and alkaline earth metals or hydrated aluminoslicate alkali metals with negatively charged positions that can remove metals very efficiently (Radziemska and Mazur, 2016: Shahbaz et al., 2018b).

\section{MATERIAL AND METHODS}

\section{Sampling site description}

The surface soil was collected from $0-15 \mathrm{~cm}$ depth by the following the random sampling method at agricultural land of Gujiao in Taiyuan City, Shanxi Province, China. Its geographical area lies between $37^{\circ} 40^{\prime}-38^{\circ} 8^{\prime}$ north latitude and $111^{\circ} 43^{\prime}-112^{\circ} 21^{\prime}$ east longitude. Gujiao has a lot of minerals, especially coal. The area of the coal mine covers about 754 square kilometers, and coal reserves represent about 8.04 billion tons. The iron ore reserves are about 30 million tons. The bauxite reserves are approximately 65.9 million tons. The limestone reserves are about 5.6 Million tons. The dolomite reserves are about 2.65 billion tons. The CBM's reserves represent nearly 5.66 billion cubic meters. The Surface soil samples were collected from different point from the fields and mixed thoroughly to obtain a homogenized sample which was used for further analysis and studies.

\section{Characterization of soil samples}

The soil samples were collected to examine different soil properties (Table 1). For the physical and chemical analyses, the soil samples were sieved through $2 \mathrm{~mm}$ mesh, while the soil samples used to determine heavy metal concentrations were sieved through a mesh having size of $1 \mathrm{~mm}$. The soil texture was determined using the hydrometer method. In order to determine the $\mathrm{pH}$ of soil, a potentiometric method was used, followed by a soil paste saturated with distilled water with 1:5 (w:v). In order to assess the organic matter contents of soil, the tiurin method was used (Sumner and Miller, 1996). For the determination of particle size distribution of soil, the pipette method was applied. The $\mathrm{NH}_{4} \mathrm{Cl}-\mathrm{NH}_{4} \mathrm{COOH}$ method was employed for assessing the cation exchange capacity (CEC) of soil. An elemental analyzer identified the total soil nitrogen, available phosphorus, and available potassium of the control soil following the combustion method (Nelson and Sommers, 1996; Rhoades, 1982). The soil organic matter contents (SOM) were calculated using the Walkley-Black method recommended by Jackson (1962). 
Table 1. The main properties of soil of the sampling site before application of amendment

\begin{tabular}{|c|c|c|c|c|c|c|c|c|c|c|}
\hline \multirow{3}{*}{ Soil } & $\mathrm{pH}$ & $\mathrm{CEC}^{\mathrm{a}}$ & $\mathrm{OM}^{\mathrm{b}}$ & $\mathrm{N}$ & $\mathrm{P}$ available & $\mathrm{K}$ available & $\mathrm{Cd}$ & $\mathrm{Cu}$ & $\mathrm{Pb}$ & $\mathrm{Zn}$ \\
\hline & - & $\mathrm{cmol} \cdot \mathrm{kg}^{-1}$ & $\%$ & $\%$ & $\mathrm{mg} \cdot \mathrm{kg}^{-1}$ & $\mathrm{mg} \cdot \mathrm{kg}^{-1}$ & $\mathrm{mg} \cdot \mathrm{kg}^{-1}$ & $\mathrm{mg} \cdot \mathrm{kg}^{-1}$ & $\mathrm{mg} \cdot \mathrm{kg}^{-1}$ & $\mathrm{mg} \cdot \mathrm{kg}^{-1}$ \\
\hline & 7.65 & 10.14 & 2.21 & 0.11 & 15.6 & 107.3 & 4.83 & 249.3 & 416 & 316 \\
\hline
\end{tabular}

${ }^{\mathrm{a}}$ Cation Exchange Capacity.

b Organic Matter.

\section{Zeolite properties}

The 'clinoptilolite' zeolite used in the experiment was purchased from a company in Taiyuan, China. It was characterized by the following physiochemical properties EC $\left(2.1 \pm 0.1 \mathrm{dSm}^{-1}\right), \mathrm{pH}$ (8.1 \pm 0.2$),$ CEC $\left(127 \pm 5.3 \mathrm{cmol} \cdot \mathrm{kg}^{-1}, 0.052 \mathrm{mg} \cdot \mathrm{kg}^{-1}\right.$ $\mathrm{Cd}, 10.42 \mathrm{mg} \cdot \mathrm{kg}^{-1} \mathrm{~Pb}, 10.25 \mathrm{mg} \cdot \mathrm{kg}^{-1} \mathrm{Cu}$ and $7.2 \mathrm{mg} \cdot \mathrm{kg}^{-1} \mathrm{Zn}$ ). The zeolite was finely mixed. Before use, the zeolite was passed through the $0.2 \mathrm{~mm}$ sieve before conditioning and measuring capacity.

\section{Pot experiment}

In this study, a pot experiment was carried out in the experimental laboratory of College of Environmental Science and Engineering, Taiyuan University of Technology, China. This pot experiment was comprised of total 11 treatments with five replicates. All the pots were filled with $1000 \mathrm{~g}$ of dry sifted soil taken from the sampling points. The treatments applied were the addition of zeolite at different concentrations i.e., 1, 3, 5, 7, 9, 13, $15,20,40$, and $50 \mathrm{~g} \mathrm{~kg}^{-1}$ as well as a control treatment where no $\mathrm{ZL}$ was added. All the treatments were arranged according to completely randomized design (CRD). The zeolite was uniformly mixed in all the pots. All samples were incubated under controlled conditions where a temperature of $25^{\circ} \mathrm{C}$ and $40 \%$ relative humidity were maintained. Moreover, water holding capacity (WHC) of the pot was maintained at $65 \%$ by adding the required amount of water after every two days. The soil samples were incubated for three different periods i.e., 30 days, 60 days and 90 days. The treatments and incubation conditions were the same during the whole experimental period. After each incubation period, the required amount of soil sample was taken and dried at room temperature for further analysis.

\section{Soil analysis}

Soil organic carbon contents (SOC) was measured using $0.2 \mathrm{~mm}$ of fine blended soil treated with dichromate and was titrated with ammonium ferrous sulfate (Walkely and Black, 1934). However, extraction of heavy metals was performed using 20 grams of finely mixed soil followed by the addition of $40 \mathrm{ml}$ of extracts solution (DTPA$\mathrm{CaCl}_{2}$-TEA having $\mathrm{pH} 7.3$ and $\mathrm{NH}_{4} \mathrm{NO}_{3}$ ). All the soil samples were centrifuged at $5000 \mathrm{rpm}$ for 1 hour and then filtered through $0.2 \mu \mathrm{m}$ Whatman filter. All the transparent solutions obtained after extraction were analyzed by atomic absorption spectrophotometer to determine the heavy metals contents in the soil.

\section{Statistical analysis}

In order to obtain the importance of all variables present between treatments, one-way analysis of variance was performed. However, significant difference $(p>0.05)$ between all the variables with in treatments was achieved through the Tukey's HSD test. All the data was analyzed using SPSS version 1.8 (released SPS. Inc.).

\section{RESULTS AND DISCUSSION}

In this study, the efficiency of in situ immobilization of heavy metals in soil was assessed by adding zeolite and using a chemical extraction test of DTPA and $\mathrm{NH}_{4} \mathrm{NO}_{3}$. The objectives of this experiment was not to eliminate the heavy metals from the soil but to minimize the useful amount of heavy metals by altering some basic soil characteristics, including soil $\mathrm{pH}$ and CEC.

\section{Effect of amendment on the soil pH}

Soil $\mathrm{pH}$ is a fundamental and essential factor that significantly influences the metal behavior in soil and affects the effectiveness and toxicity to the soil and plants, both directly or indirectly (Radziemska, 2018). As shown in Figure 1, the soil taken from experimental field was moderately alkaline, and recorded average soil $\mathrm{pH}$ of the controlled pot was 7.65. Due to the strong alkaline $\mathrm{pH}$, application of zeolite increased the $\mathrm{pH}$ of soil 


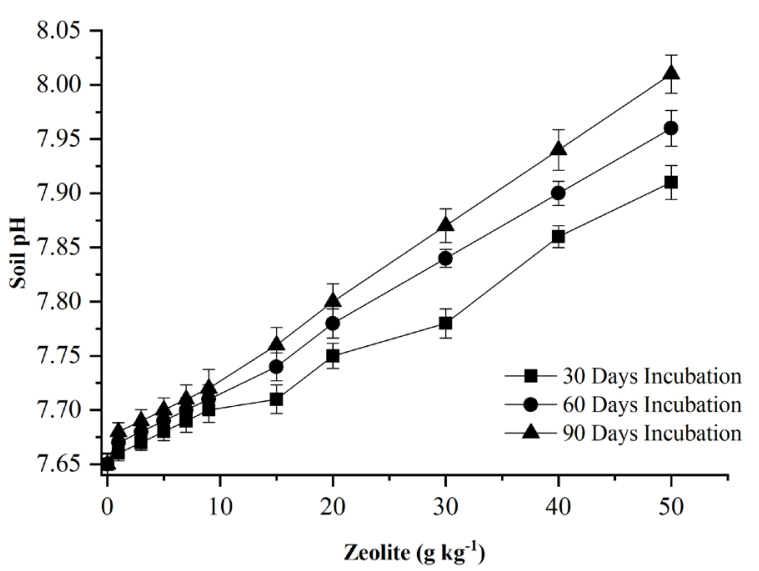

Fig. 1. Effect of amendments on the change in soil $\mathrm{pH}$ over control treatment

( $p$ > 0.05) (Querol et al., 2006). All other treatments also significantly increased the $\mathrm{pH}$ of soil as compared to the control treatment. Radziemska (2018) observed that the addition of zeolite resulted in a significant increase in the soil $\mathrm{pH}$ and promoted carbonate precipitation and oxide formation, thereby reducing the quantity of heavy metals in the soil. The content of amendments added and the incubation time have a substantial effect on the immobilization of heavy metals and the increase in pH of soil (Dang et al., 2019).

The results presented in Figure 1 illustrate that variable addition of zeolite ranging from $1 \mathrm{~g} \cdot \mathrm{kg}^{-1}$ to $50 \mathrm{~g} \cdot \mathrm{kg}^{-1}$ and incubation time $(30,60$, 90 days) influences the soil $\mathrm{pH}$. The incubation period exhibited significant differences in the soil $\mathrm{pH}$ and these differences were more prominent in treatments where higher doses of zeolite were used i.e., $50 \mathrm{~g} \cdot \mathrm{kg}^{-1}$. The soil $\mathrm{pH}$ of the samples up to $1-9{\mathrm{~g} \cdot \mathrm{kg}^{-1}}^{-}$of the zeolite with minimum incubation time of 30 days differ from the controlled treatment with the same incubation time 7.65-7.70, while only a slight increment was observed from 7.65-7.71 when the incubation time was enhanced to 60 days with same amount of amendment, but the difference in soil $\mathrm{pH}$ between the 30 and 60 days of incubation was very close. The $\mathrm{pH}$ of the soil samples incubated for 90 days increased significantly by $7.65-7.72$. Therefore, positive increments occurred in the 90 day as compared to 30 and 60 days incubation results. Similarly, as the quantity of amendment and incubation time were increased, as a significant effect of both the factors simultaneously, the highest soil $\mathrm{pH}$ recorded was 8.01 at incubation with $50 \mathrm{~g} \cdot \mathrm{kg}^{-1}$ zeolite for 90 days, which was constantly significant compared to the control and all other treatments. Therefore, it can be concluded that Zeolite has a significant effect of increasing the $\mathrm{pH}$ of soil and the addition of zeolite has increased $5.29 \% \mathrm{pH}$ of the soil as compared to the control treatment.

The beet lime and biosolids compost were used for 2 years under field conditions as amendments, which changed the $\mathrm{pH}$ of the soil (Madejón et al., 2009). Since most heavy metals have very low mobility under alkaline conditions, increasing the soil $\mathrm{pH}$ can often remediate the contamination in soil by heavy metals (Teng et al., 2015). There are different processes including selective adsorption, metal precipitation with oxides, hydroxides, phosphates and carbonates to reduce the mobility of metals in soil solution which increase the soil fertility and promote the plant growth by providing the best conditions (Cárcamo et al., 2012).

\section{Effect of amendments on the soil cation exchange capacity}

Figure 2 shows the effects of addition of zeolite on CEC of soil samples during different incubation times. The results showed that the soil CEC increased significantly after the application of the zeolite in the soil samples compared to the non-amended soil samples. CEC is a significant factor in the immobilization of heavy metals (Sneddon et al., 2006). When the dose of up to $9 \mathrm{~g} \mathrm{~kg}^{-1}$ zeolite was added, the soil CEC did not change significantly. However, the incubation time had a significant effect, and the soil CEC increased from $10.14-10.25 \mathrm{cmol} \cdot \mathrm{kg}^{-1}$ when the soil was treated with $9 \mathrm{~g} \mathrm{~kg}^{-1}$ zeolite and incubated for 90 days, which was a considerable difference

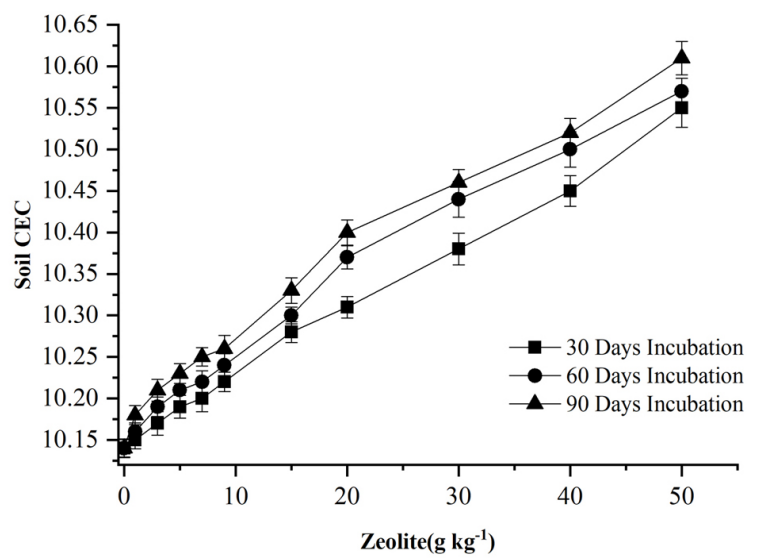

Fig. 2. Effect of amendments on the change in soil CEC over control treatment 
compared to the control treatment. When $50 \mathrm{~g} \cdot \mathrm{kg}^{-}$ ${ }^{1}$ zeolite was added for 90 days incubation, the maximum CEC reached $10.61 \mathrm{cmol} \cdot \mathrm{kg}^{-1}$. On the basis of the results, it can be concluded that there is a positive significant effect of zeolite on the soil $\mathrm{CEC}$, and the addition of zeolite in the amount of $50 \mathrm{~g} \cdot \mathrm{kg}^{-1}$ has increased the soil CEC up to $4.31 \%$, as compared to the control treatment.

As the amount of zeolite added increased from $10 \mathrm{~g} \cdot \mathrm{kg}^{-1}$ to $20 \mathrm{~g} \cdot \mathrm{kg}^{-1}$, the soil CEC increased significantly (Li et al., 2009). Due to its high specific surface area and high CEC, zeolite plays an essential role in surface complexation and significantly increases soil CEC also (Querol et al., 2006).

\section{Effect of amendments on the availability of heavy metals in soil}

All zeolite amendments significantly reduced the concentration of extractable heavy metals in the soil samples compared to the control treatment. Although the extent of the effect depends on two factors, the amount of zeolite and heavy metals. Zeolite significantly reduced the amount of DTPA and $\mathrm{NH}_{4} \mathrm{NO}_{3}$ extractable heavy metals in the soil samples during all three incubation times. According to Figures 3 and 4, after 90 days of incubation, up to $9 \mathrm{~g} \cdot \mathrm{kg}^{-1}$ zeolite content reduced the DTPA extractable $\mathrm{Cd}$ and $\mathrm{Pb}$ concentration in the soil samples from 4.96 (control) to $4.89 \mathrm{mg} \cdot \mathrm{kg}^{-1}$ for $\mathrm{Cd}$ and 416 (control) to $391 \mathrm{mg} \cdot \mathrm{kg}^{-1}$ for $\mathrm{Pb}$. The same reduction trend was noted when the amount of zeolite increased from $15-50 \mathrm{~g} \cdot \mathrm{kg}^{-1}$ at the same incubation time. When the soil samples were incubated for 90 days with $50 \mathrm{~g} \cdot \mathrm{kg}^{-1}$ zeolite, the best effect of zeolite amendment was observed and DTPA extractable concentration was up to $4.66 \mathrm{mg} \cdot \mathrm{kg}^{-1}$ and $316 \mathrm{mg} \cdot \mathrm{kg}^{-1}$ for $\mathrm{Cd}$ and $\mathrm{Pb}$ respectively, which is more significant than all other treatments.

According to some scientists, DTPA is the best extractant and suitable for calcareous soil because it is buffered at $7.3 \mathrm{pH}$, thus preventing the dissolution and release of $\mathrm{CaCO}_{3}$. There is a high concentration of $\mathrm{CaCl}_{2}$ in the DTPA extractant in which $\mathrm{Ca}^{+2}$ can be rapidly exchanged with bivalent cations; this exchange is quicker especially with the $\mathrm{Cd}$ contaminated soils. The greater concentration of chloride ions makes a complex of these two elements and triethanolamine (TEA) that is buffered at $\mathrm{pH} 7.3$ can replace the $\mathrm{H}^{+}$with cations at exchanging site. The findings of such extraction studies can be more reliable to study the effectiveness of soil amendments (Lin and Zhou, 2009).

Our findings indicate that the soil $\mathrm{pH}$ significantly increased after the application of zeolite, resulting in high retention of the heavy metals at solid phase in soil, and the metal retention of zeolite may increase due to the effect of lime. The zeolite can fix heavy metals in the mineral clay layer of the soil by diffusion and increase the $\mathrm{pH}$ of the soil for a longer time (Lahori et al. 2017). The application of zeolite has significant effects on the immobilization of heavy metals, so the amount of metals in the soil becomes reduced and the roots of plants can make full use of heavy metals as previously explained by Trakal et al. (2011) who noticed that the willow tree's ability to absorb heavy metals decreased significantly after the zeolite application in the soil.

$\mathrm{NH}_{4} \mathrm{NO}_{3}$ is the mild extractant as compared to DTPA which can easily extract the fraction of exchangeable heavy metals in the soil solution. Therefore, the concentration of heavy metals is comparatively lesser in this extractant as compared to the others, especially DTPA. The reason behind this low fraction is the soil $\mathrm{pH}$, because the availability of metals is directly dependent on the soil $\mathrm{pH}$, and the concentration of $\mathrm{NH}_{4} \mathrm{NO}_{3}$ extractable concentration reflects the effect of amendments of soil $\mathrm{pH}$.

All zeolite amendments reduced the content of heavy metals in the soil, compared to the non-amended soil samples extracted with $1 \mathrm{M}$ $\mathrm{NH}_{4} \mathrm{NO}_{3}$. According to Figures 5 and 6, after 30 days of incubation, up to $9 \mathrm{~g} \cdot \mathrm{kg}^{-1}$ zeolite content reduced the $\mathrm{NH}_{4} \mathrm{NO}_{3}$ extractable $\mathrm{Cd}$ and $\mathrm{Pb}$ concentration in the soil samples from 4.76 (controlled) to $4.59 \mathrm{mg} \cdot \mathrm{kg}^{-1}$ for $\mathrm{Cd}$ and $416 \mathrm{mg} \cdot \mathrm{kg}^{-1}$ (control) to $401 \mathrm{mg} \cdot \mathrm{kg}^{-1}$ for $\mathrm{Pb}$, which was not much different from controlled treatment. The addition of $15-50 \mathrm{mg} \cdot \mathrm{kg}^{-1}(\mathrm{ZL})$ with the same incubation time and the result was $4.02 \mathrm{mg} \cdot \mathrm{kg}^{-1}$ and $319 \mathrm{mg} \mathrm{kg}^{-1}$ for $\mathrm{Cd}$ and $\mathrm{Pb}$ at addition of $50 \mathrm{~g} \cdot \mathrm{kg}^{-1}$ zeolite. The values of the $\mathrm{Cd}$ and $\mathrm{Pb}$ (extracted with $1 \mathrm{M} \mathrm{NH}_{4} \mathrm{NO}_{3}$ ) contents in the soil without any change in amendment (ZL) level also decreased $4.68-3.91 \mathrm{mg} \cdot \mathrm{kg}^{-1}$ and $416-332 \mathrm{mg} \cdot \mathrm{kg}^{-1}$ as the incubation time was increased to 60 days.

The best result was achieved when the samples with $50 \mathrm{~g} \cdot \mathrm{kg}^{-1}$ zeolite were incubated for 90 days and the values reached up to $3.86 \mathrm{mg} \cdot \mathrm{kg}^{-1}$ $\mathrm{Cd}$ and $346 \mathrm{mg} \cdot \mathrm{kg}^{-1}$. According to the results, the content of reduction in $\mathrm{NH}_{4} \mathrm{NO}_{3}$ extractable $\mathrm{Cd}$ is 
significantly greater than the results of the DTPA extraction. In turn, the reduction in the $\mathrm{Pb}$ content in lesser by $\mathrm{NH}_{4} \mathrm{NO}_{3}$ than DTPA.

It was noticed that zeolite decreased the concentration of $\mathrm{Cd}$ by $5.51 \%, 16.09 \%$ and of $\mathrm{Pb}$ by $23.5 \%, 20.11 \%$, as compared to the controlled treatment extracted with DTPA and $\mathrm{NH}_{4} \mathrm{NO}_{3}$ solution.

a)

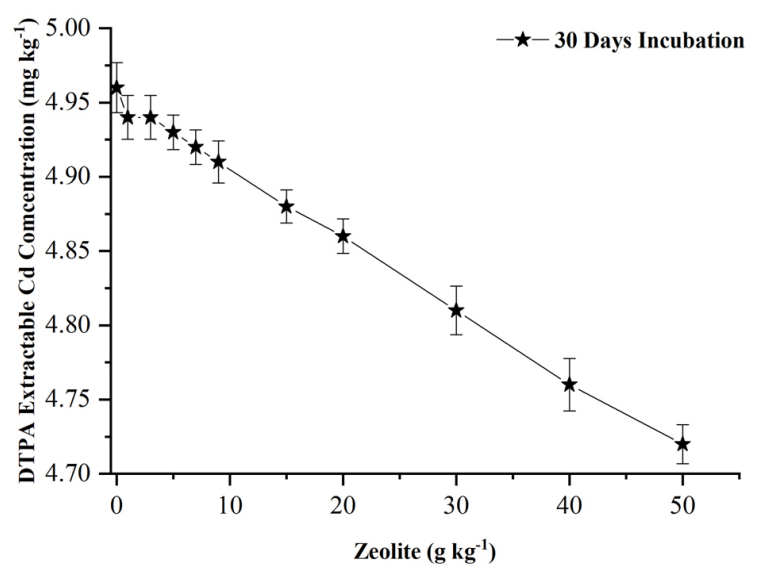

b)

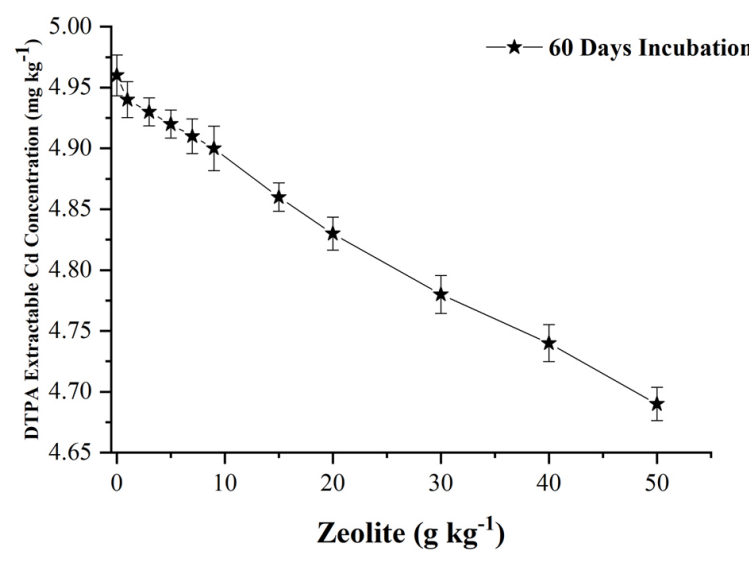

c)

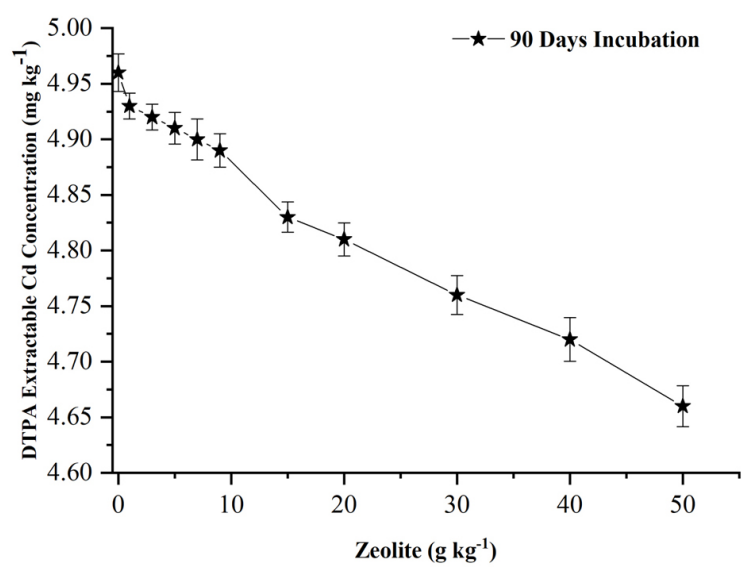

Fig. 3. Effect of amendments on the change in the concentration of $\mathrm{Cd}$ extracted with DTPA solution over control treatment
The DTPA extractable concentration of $\mathrm{Cu}$ and $\mathrm{Zn}$ is shown in Figures 7 and 8. The concentration of $\mathrm{Cu}$ and $\mathrm{Zn}$ in the soil samples amended with zeolite is significantly different from that of control, which indicates the effects of zeolite on the $\mathrm{Cu}$ and $\mathrm{Zn}$ concentration. On the contrary, it can be seen from Figure 7 and 8 that the

a)

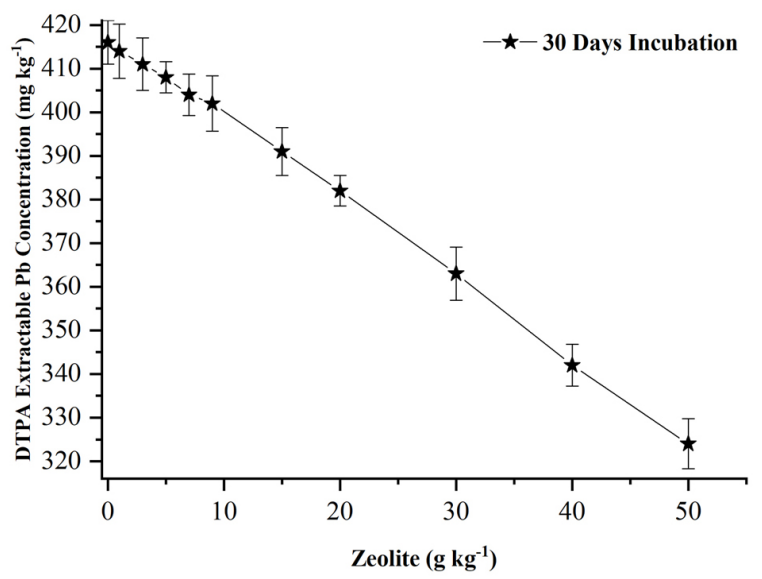

b)

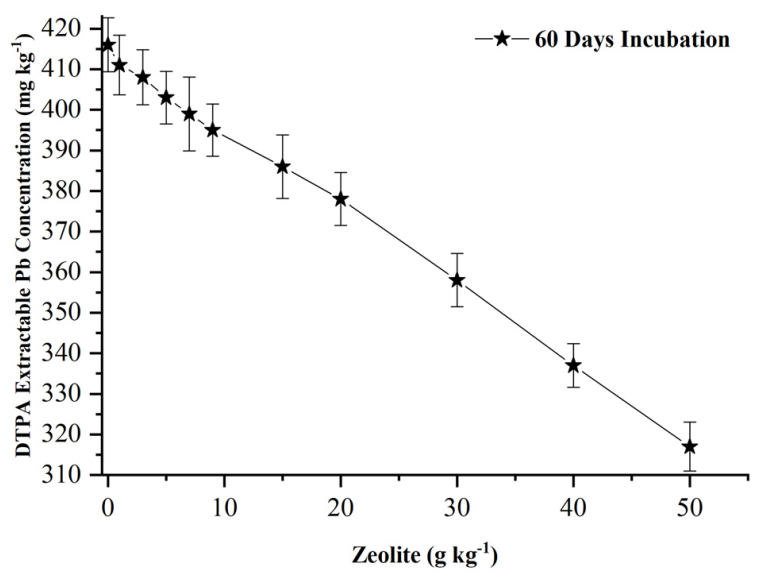

c)

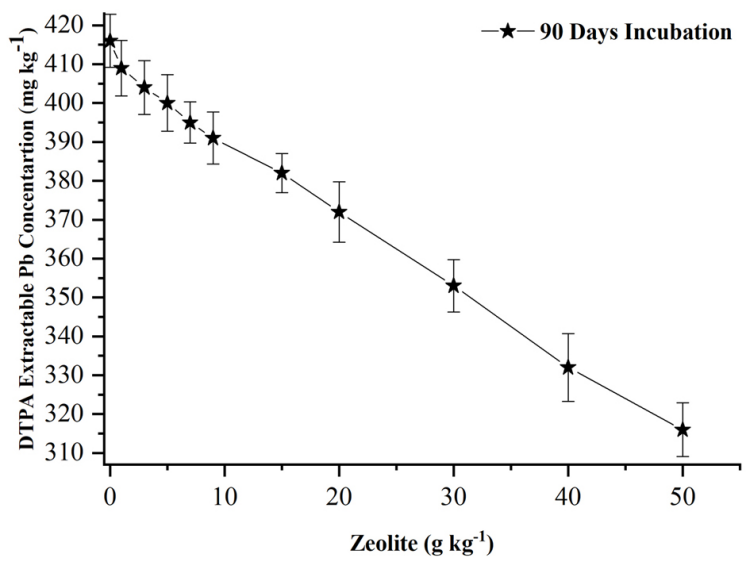

Fig. 4. Effect of amendments on the change in the concentration of $\mathrm{Pb}$ extracted with DTPA solution over control treatment 
incubation time also has positive influence on the mobility of $\mathrm{Cu}$ and $\mathrm{Zn}$. Both the incubation time and amount of zeolite decreased the $\mathrm{Cu}$ and $\mathrm{Zn}$ concentration with the following order (highest to lowest) control $>1-50 \mathrm{~g} \mathrm{~kg}^{-1}$ simultaneously.

According to our results, the effect of zeolite with a minimum concentration and a minimum incubation time of 30 days is not obvious,

a)

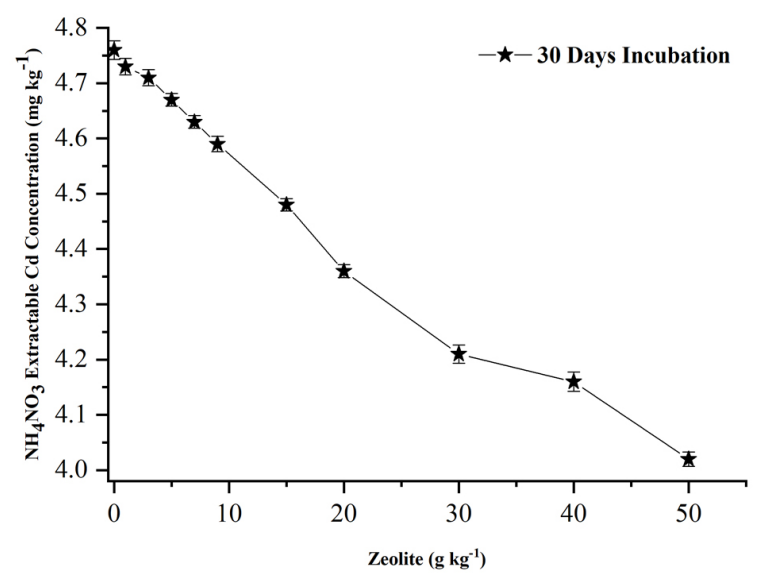

b)

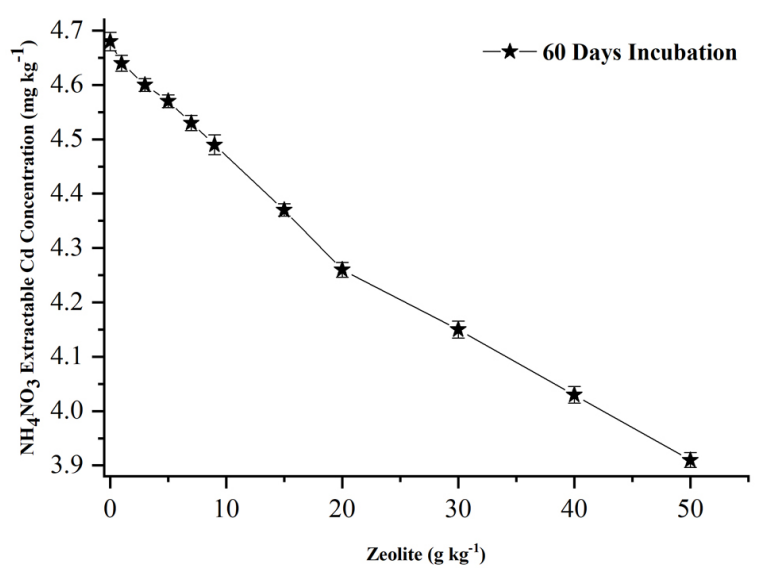

c)

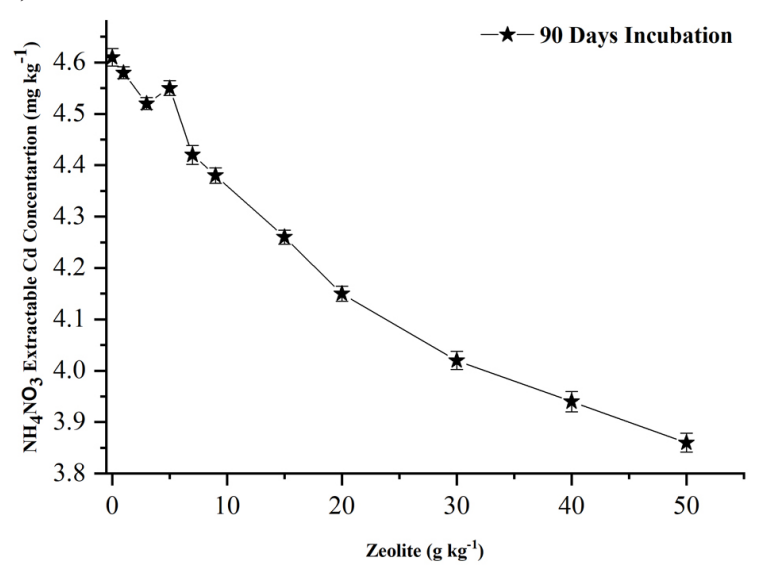

Fig. 5. Effect of amendments on the change in the concentration of $\mathrm{Cd}$ extracted with $\mathrm{NH}_{4} \mathrm{NO}_{3}$ solution over control treatment and only a small amount of DTPA extractable $\mathrm{Cu}$ and $\mathrm{Zn}$ has decreased from $258 \mathrm{mg} \cdot \mathrm{kg}^{-1}$ to $265 \mathrm{mg} \cdot \mathrm{kg}^{-1}$ and 318 to $295 \mathrm{mg} \cdot \mathrm{kg}^{-1}$. These results have a significant impact, and with increasing incubation time and amount of zeolite added, after $50 \mathrm{~g} \cdot \mathrm{kg}^{-1}$ of zeolite and 90-day incubation and the concentration of DTPA extractable $\mathrm{Cu}$ decreases to $168 \mathrm{mg} \cdot \mathrm{kg}^{-1}$, while the DTPA extractable

a)

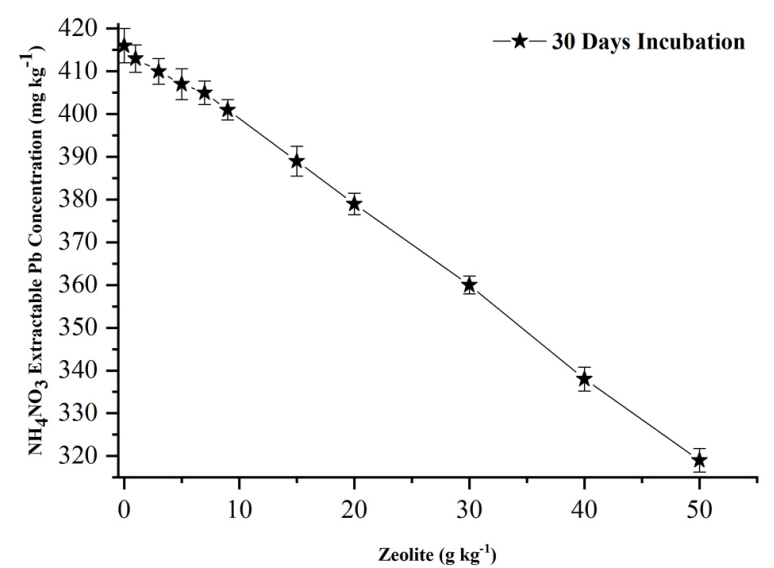

b)

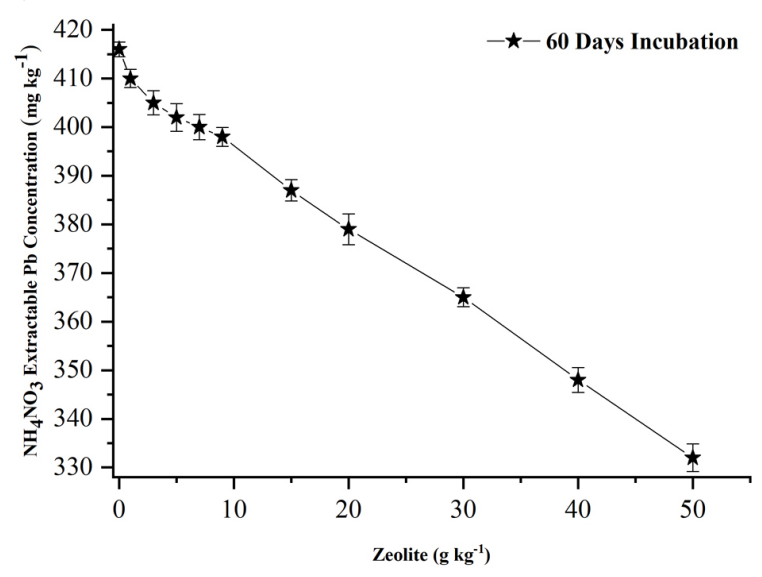

c)

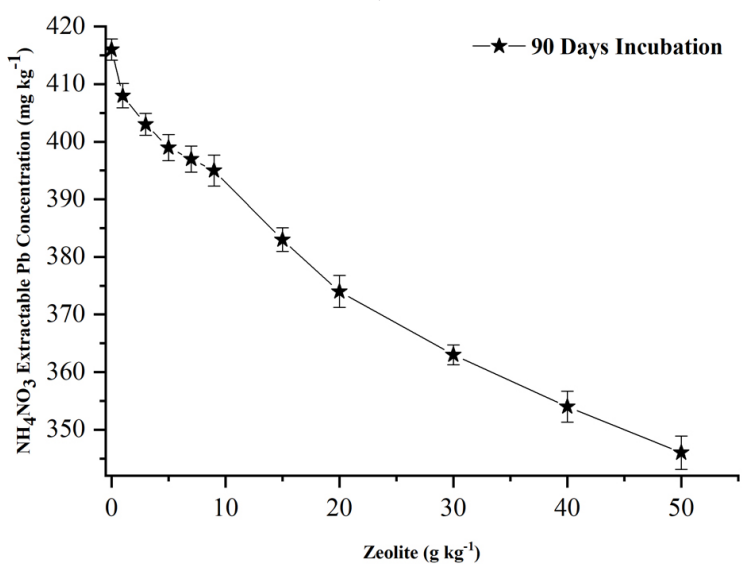

Fig. 6. Effect of amendments on the change in the concentration of $\mathrm{Pb}$ extracted with $\mathrm{NH}_{4} \mathrm{NO}_{3}$ solution over control treatment 
concentration of $\mathrm{Zn}$ decreased to $224 \mathrm{mg} \mathrm{kg}^{-1}$, which is very significant compared to all other treatments. This reduction is 35.66 and $28.41 \%$ for $\mathrm{Cu}$ and $\mathrm{Zn}$, respectively, as compared to the controlled treatment.

Compared with the control by immobilization in soil samples, the heavy metal content was significantly reduced after applying natural zeolite

a)

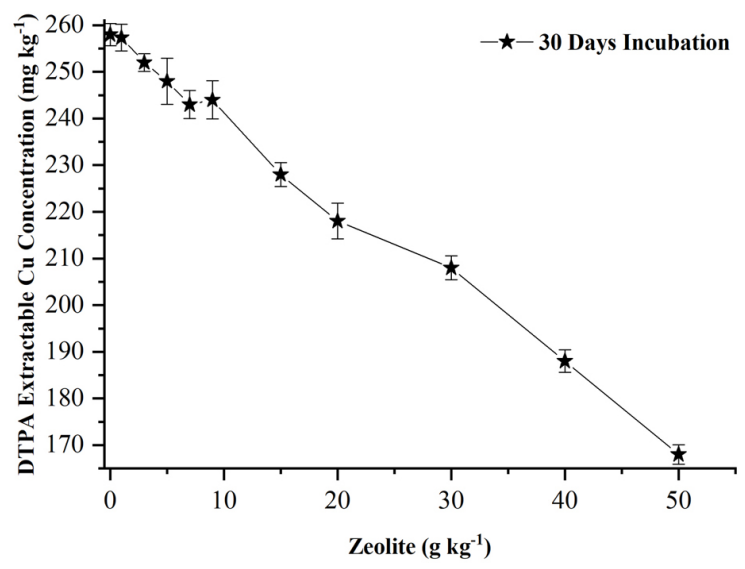

b)

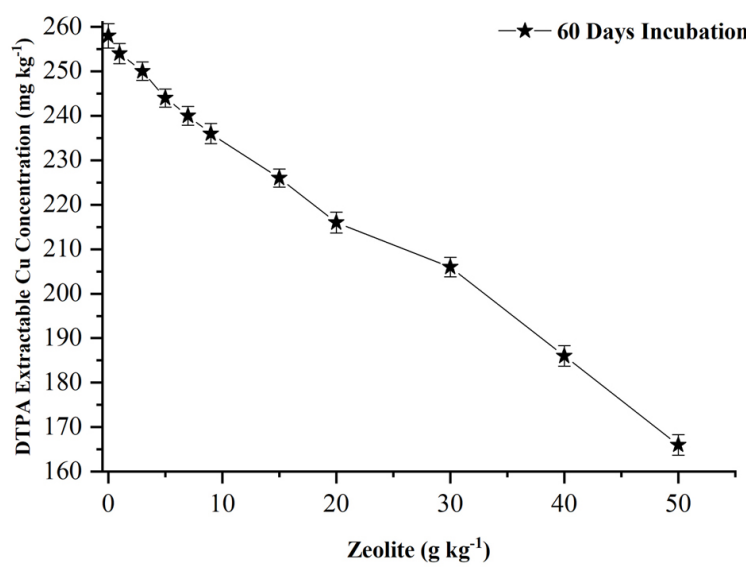

c)

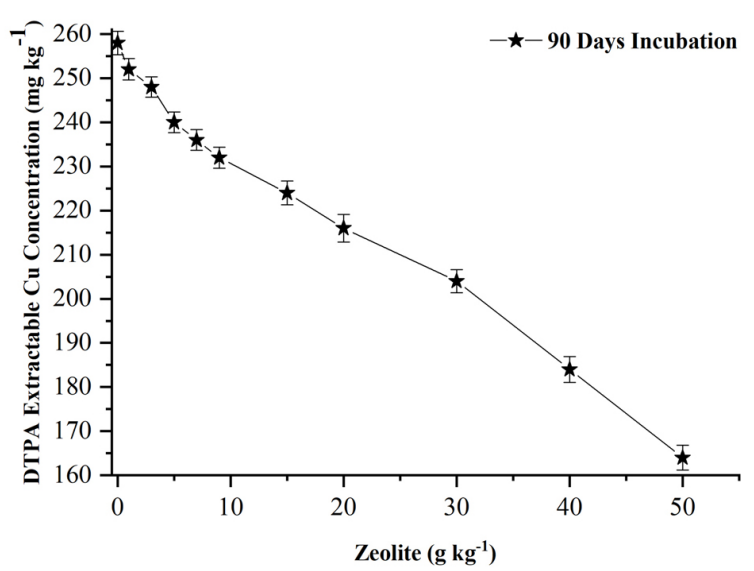

Fig. 7. Effect of amendments on the change in the concentration of $\mathrm{Cu}$ extracted with DTPA solution over control treatment $\left(90 \mathrm{t} \cdot \mathrm{ha}^{-1}\right)$, but this reduction in the heavy metal content was lower than that of dolomite and bentonite. These results belong to an experimental study by Szakova et al. (2007), who noticed that the extractable heavy metal concentration reached a minimum effect after applying zeolite. According to their results, the extractability was reduced by only $30 \%$ after applying natural

a)

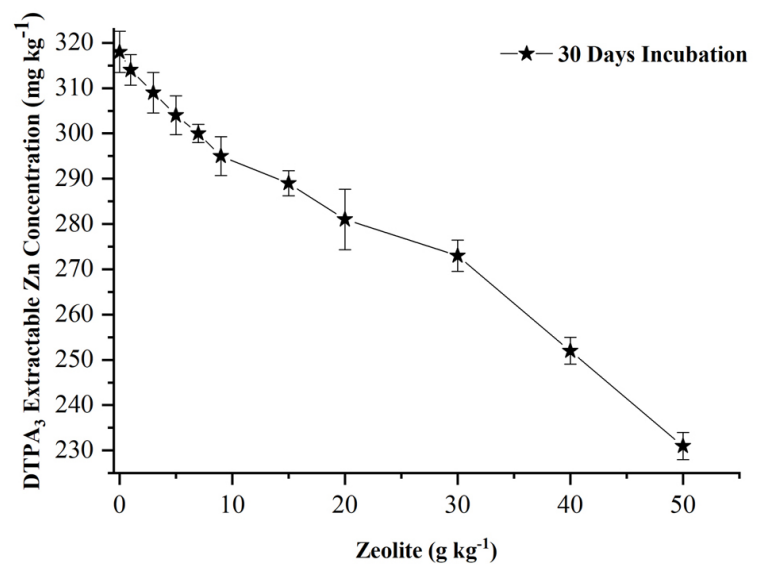

b)

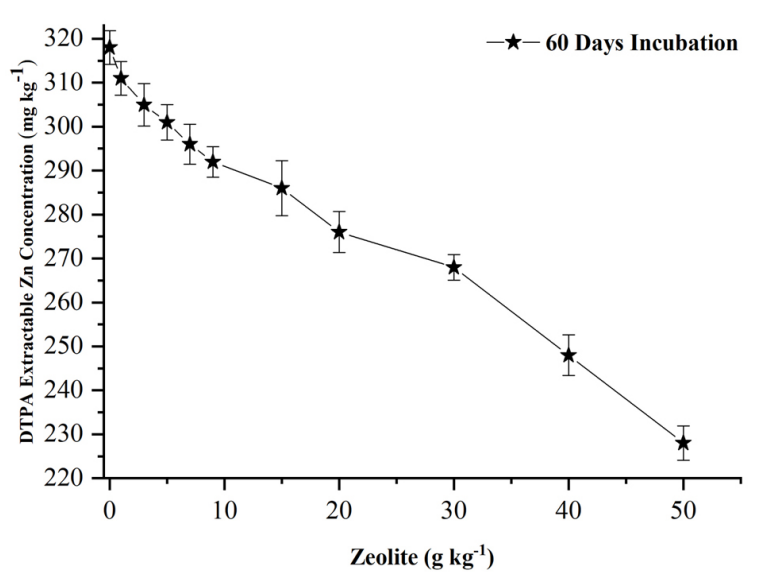

c)

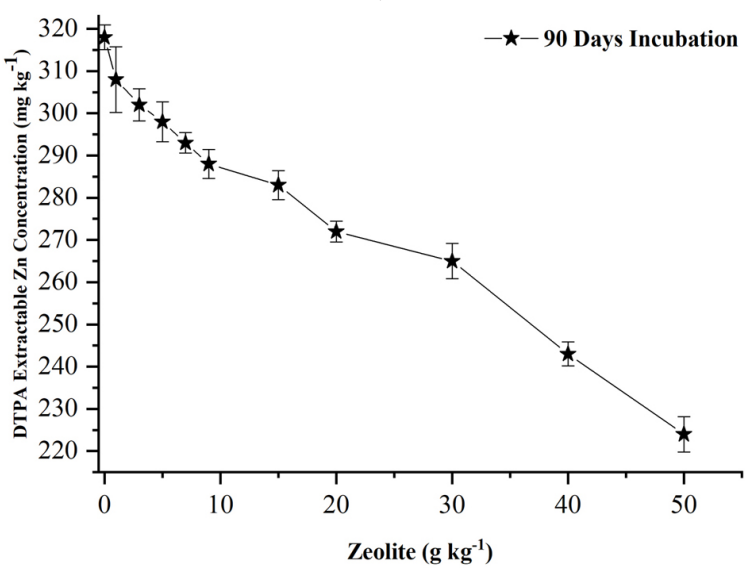

Fig. 8. Effect of amendments on the change in the concentration of $\mathrm{Zn}$ extracted with DTPA solution over control treatment 
zeolite. Usman et al. (2005) also obtained similar results in their research, namely the use of clay minerals to fix heavy metals.

A similar reduction was noticed when the soil samples were extracted with $1 \mathrm{M} \mathrm{NH}_{4} \mathrm{NO}_{3}$ solution, and it can be seen from Figure 9 and 10 that the zeolite (ZL) also has positive role in immobilizing $\mathrm{Cu}$ and $\mathrm{Zn}$ extraction with $1 \mathrm{M} \mathrm{NH}_{4} \mathrm{NO}_{3}$.

a)

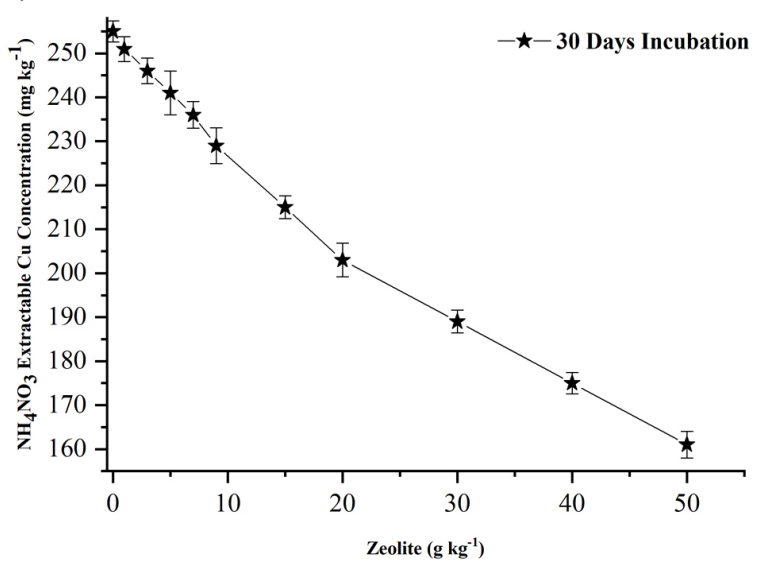

b)

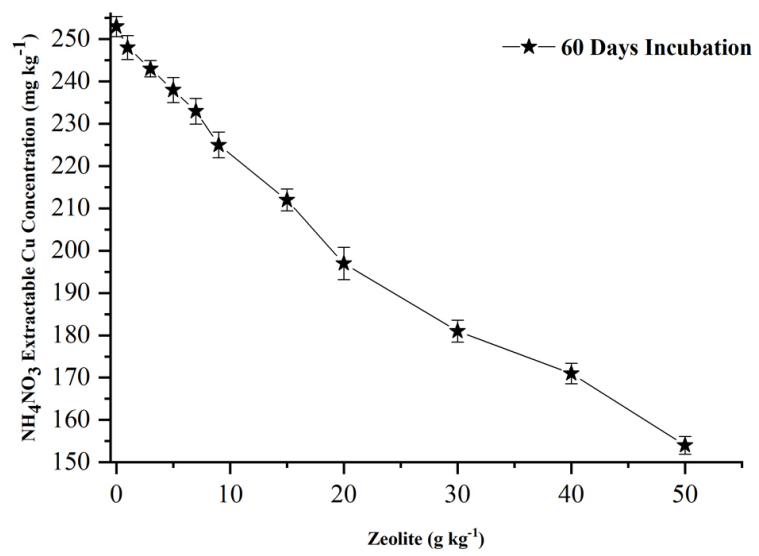

c)

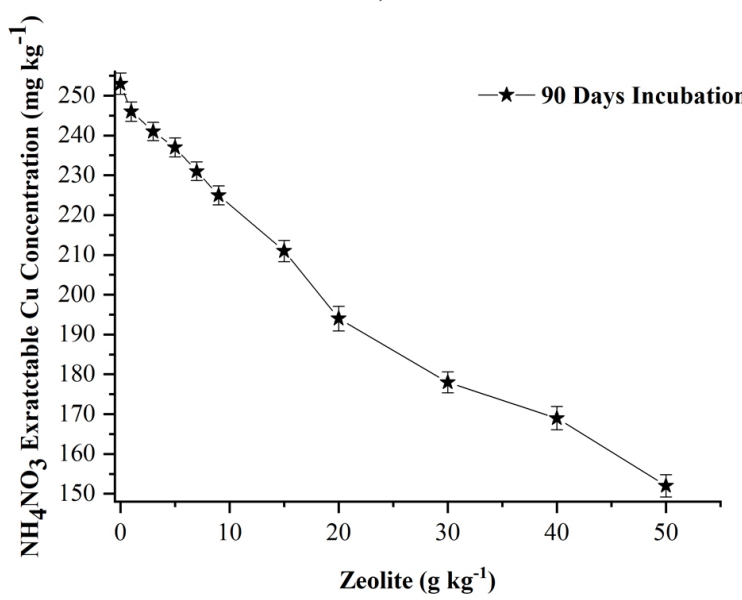

Fig. 9. Effect of amendments on the change in the concentration of $\mathrm{Cu}$ extracted with $\mathrm{NH}_{4} \mathrm{NO}_{3}$ solution over control treatment
According to our results, the effects of zeolite with a maximum concentration of $50 \mathrm{~g} \cdot \mathrm{kg}^{-1}$ and a minimum incubation time of 30 days were obvious, and only a significant amount of $\mathrm{NH}_{4} \mathrm{NO}_{3}$ extractable $\mathrm{Cu}$ has decreased from $255 \mathrm{mg} \cdot \mathrm{kg}^{-1}$ to $161 \mathrm{mg} \cdot \mathrm{kg}^{-1}$, while the $\mathrm{NH}_{4} \mathrm{NO}_{3}$ extractable concentration of $\mathrm{Zn}$ reduced from $316 \mathrm{mg} \cdot \mathrm{kg}^{-1}$ to $244 \mathrm{mg} \cdot \mathrm{kg}^{-1}$ which is highly effective than

a)

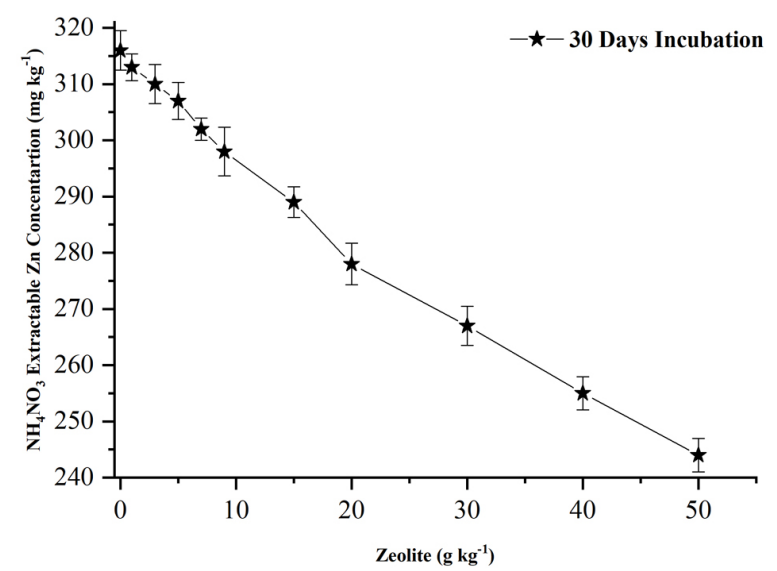

b)

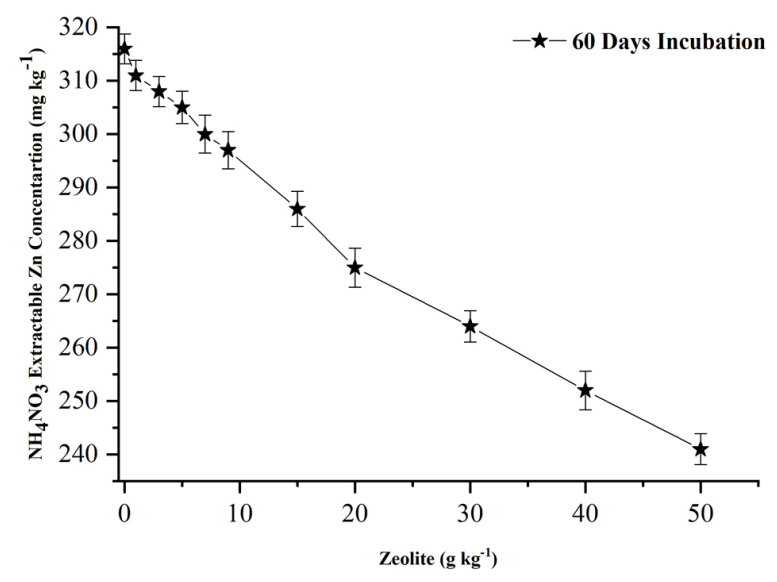

c)

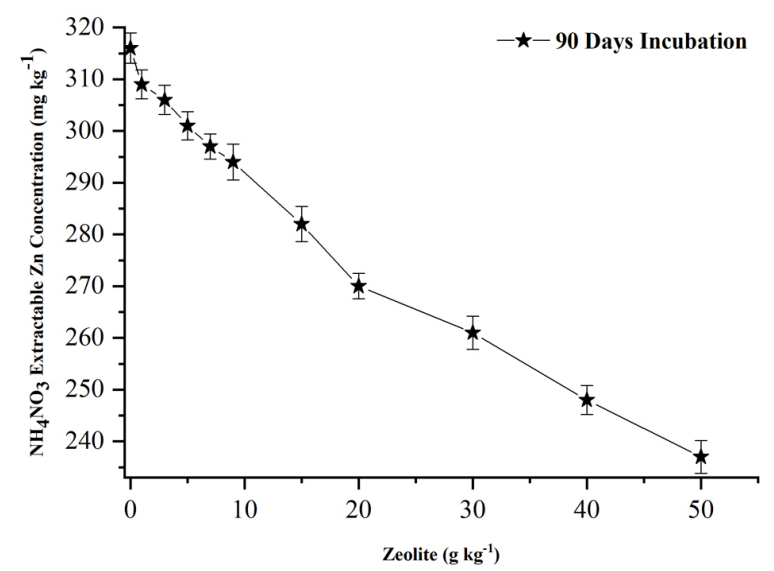

Fig. 10. Effect of amendments on the change in the concentration of $\mathrm{Zn}$ extracted with $\mathrm{NH}_{4} \mathrm{NO}_{3}$ solution over control treatment 
control and all other treatments. The results of other minimum concentrations did not differ much than the control treatment. The results of the samples incubated for 60 days without any alteration the content of amendment (ZL) had a significant effect on the decrease in the $\mathrm{Cu}$ and $\mathrm{Zn}$ concentration. The highest level of decrease was noticed $154 \mathrm{mg} \cdot \mathrm{kg}^{-1}$ and $237 \mathrm{mg} \cdot \mathrm{kg}^{-1}$ for $\mathrm{Cu}$ and $\mathrm{Zn}$ respectively, when the samples were amended with $50 \mathrm{~g} \mathrm{~kg}^{-1}$ (ZL) and incubated for 90 days. The addition of zeolite reduced $\mathrm{NH}$ ${ }_{4} \mathrm{NO}_{3}$ extractable by $35.66,38.37 \%$ and 28.41 , $23.81 \%$ for $\mathrm{Cu}$ and $\mathrm{Zn}$ extracted with DTPA and $1 \mathrm{M} \mathrm{NH} \mathrm{NO}_{3}$ solution, respectively as compared to the controlled treatment.

\section{CONCLUSION}

The main purpose of this study was to compare the effectiveness of zeolite aiming at the reduction behavior of negative effects of soil pollutants. The proposed results suggest that zeolite is highly beneficial for the decontamination of polluted soil.

- Zeolite can increase the $\mathrm{pH}$ and CEC of soil and immobilize the heavy metals in soil, thus it can reduce its availability and reduce the toxicity of pollutants in the soil.

- Zeolite amendments were effective for reducing the mobility of heavy metals due to binding of metals and forming the complexes.

- Although these amendments reduced the concentration of heavy metals in the soil, the best results achieved at dose of $50 \mathrm{~g} \cdot \mathrm{kg}^{-1}$.

- According to the results, the retention time also influenced the performance of zeolite.

- The extraction behavior of both extractants (DTPA and $\mathrm{HN}_{4} \mathrm{NO}_{3}$ ) is different and both have a positive effect on the magnitude of extraction, and are efficient for the experimental studies.

- Despite encouraging finding, the tested amendment will be applied under the field conditions for the further evaluation in the future, specifically in historically polluted areas; as time goes by, more pay attention to metals, as our results show that the application of amendments reduces the environmental risks.

\section{Acknowledgment}

The funding of this work was supported by the National Nature Science Foundation of China (No.21701099) and the Basic Research Program of Shanxi Province, China (No.201801D121267).

\section{REFERENCES}

1. Aryal, R., Nirola, R., Beecham. S., Sarkar, B., 2016. Influence of heavy metals in root chemistry of Cyperus Vaginatus R.Br: a study through optical spectroscopy. Int. Biodeterior. Biodegr. 133, 201-207.

2. Ayari, F., Hamdi, H., Jeddidi, N., Gharbi, N., Kossai, R., 2010. Heavy metal distribution in soil and plant in municipal solid waste compost amended plots. Int. J. Environ. Sci. Technol. 7, 465-472.

3. Bian, R., Joseph, S., Chia, C., Marjof, C., Gong, B., Munroec, P., Donneda, S., 2014. A three-year experiment confirms continuous immobilization of cadmium and lead contaminated paddy field with biochar amendment. J. Hazard. Mater. 272, 121-128.

4. Bolan, N., Kunhikrishnan, a., Thangarajan, R., Kumpiene, J., Park, J.H., Makino, T., Kirkham, M.B., Scheckel, K., 2014. Remediation of heavy metal (liod) s contaminated soil to mobilize or to immobilize? J. Hazard. Mater. 266, 141-166.

5. Borowski, G., Kujawska, J., \& Wasąg, H. (2019). Application of zeolites in removal of hazardous metal ions from drilling mud wastewater. Physicochem. Probl. Miner. Process, 55(6), 1467-1474.

6. Cárcamo, V., Bustamante, E., Trangolao, E., De La Fuente, L.M., Mench, M., Neaman, A., Ginocchio, R., 2012. Simultaneous immobilization of metals and arsenic in acidic polluted soils near a copper smelter in central Chile. Environ. Sci. Pollut. Res. https:// doi.org/10.1007/s11356-011-0673-3.

7. Cheung, K.H., Gu, J.d., 2007. Mechanism of hexavalent chromium detoxification by microorganisms and bioremediation application potential; a review. Int. Biodeterioi. Biodegr. 59, 8-15.

8. Dang, V. M., Joseph, S., Van, H. T., Mai, T. L. A., Duong, T. M. H., Weldon, S. \& Taherymoosavi, S. (2019). Immobilization of heavy metals in contaminated soil after mining activity by using biochar and other industrial by-products: the significant role of minerals on the biochar surfaces. Environ. Tech. 40(24), 3200-3215.

9. Houben, D., Evrard, L., Sonnet, P., 2013. Mobility, bioavailability and $\mathrm{pH}$-dependent leaching of cadmium, zinc and lead in a contaminated soil amended with biochar. Chemosphere 92, 1450-1457.

10. Jackson, V.A., Paulse, A.N., Bester, A.A., Neethling, J.H., Khan, S., Khan, W., 2009. Bioremediation of metal contamination in plankenburg river, Western Cape, South Africa. Int. Biodeterior. Biodegr. 63, 559-568.

11. Kumar, R., Bhatia, D., Singh, R., Bishnoi, N.R., 2012. Metal tolerance and sequestration of Ni (II), $\mathrm{Zn}$ (II) and Cr (VI) ions from simulated and electroplating wastewater in batch process: kinetics and equilibrium study. Int. Biodeterior. Biodegr. 66, 82-90.

12. Kumar, R.R., Park, B.J., Cho, J.Y., 2013. Application and environmental risks of livestock manure. J. 
Korean Soc. Appl. Biol. Chem. 56, 497-503.

13. Kumpience, J., Lagerkvist, A., Maurice, C., 2007. Stabilization of $\mathrm{Pb}$ - and $\mathrm{Cu}$-contaminated soil using coal fly ash and peat, Environ. Pollut. 145, 365-373.

14. Lahori, A.H., Zhang, Z., Guo, Z., Mahar, A., Li, R., Awasthi, M.K., Sial, T.A., Kumbhar, F., Wang, P., Shen, F., Zhao, J., Huang, H., 2017. Potential use of lime combine with additives on (mobilization) and phytoavailability of heavy metals from $\mathrm{Pb} / \mathrm{Zn}$ smelter contaminated soils. Ecotoxicol. Environ. Saf. 145, 313-323.

15. Li, H., Shi,W.-y, Shao, H.-b, Shao, M.-a, 2009. The remediation of the lead-polluted garden soil by natural zeolite. J. Hazard. Mater. 169, 1106-1111.

16. Liu, L.W., Li, W., Song, W.P., Guo, M.X., 2018. Remediation techniques for heavy metal contaminated soils; principles and applicability. Sci. Total Environ. 633, 206-219.

17. Luo, C., Liu, C., Wang, Y., Liu, X., Li, F., Zhang, G., Li, X., 2011. Heavy metals contamination on soils and vegetables near an e-waste processing site, south China. J. Hazard. Mater. 186, 481- 490.

18. Madejón, E., Madejón, P., Burgos, P., Pérez de Mora, A., Cabrera, F., 2009. Trace elements, pH and organic matter evolution in contaminated soils under assisted natural remediation: a 4-year field study. J. Hazard. Mater. 162, 931-938.

19. Nejad, Z. D., Jung, M. C., \& Kim, K. H. (2018). Remediation of soils contaminated with heavy metals with an emphasis on immobilization technology. Environmental geochemistry and health, 40(3), 927-953.

20. Nelson, D.W., Sommers, L.E., 1996. Total carbon, organic carbon, and organic matter. Methods of Soil Analysis, Part 3: Chemical Methods. ASA and SSSA, Madison, Wisconsin, USA, pp. 961-1010.

21. Radziemska, M., Mazur, Z., 2016. Content of selected heavy metals in Ni-Contaminated soil following the application of halloysite and zeolite. J. Ecol. Eng. 17(3), 125-133.

22. Radziemska, M., 2018. Study of applying naturally occurring mineral sorbents of Poland (dolomite, halloysite, chalcedonite) for aided phytostabilization of soil polluted with heavy metals. Catena 163, 123-129.

23. Rhoades, J.D., 1982. Cation exchange capacity. In: Page, A.L. (Ed.), Methods of Soil Analysis. Part 2, Chemical and Microbiological Properties. American Society of Agronomy Inc., Madison, pp. 149-157.

24. Shahbaz, A.K., Lewińska, K., Iqbal, J., Ali, Q., Iqbal, M., Abbas, F., Tauqeer, H.M., Ramzani, P.M.A., 2018b. Improvement in productivity, nutritional quality, and antioxidative defense mechanisms of sunflower (Helianthus annuus L.) and maize (Zea mays L.) in nickel contaminated soil amended with different biochar and zeolite ratios. J. Environ. Manag. 218, 256-270.

25. Shaheen, S.M., Hoonda, P.S., Tsadilas, C.D., 2014. Opportunities and challenges in the use of coal fly ash for soil improvements; J. Environ. Manag. 145, 249-267.

26. Sneddon, I.R., Orueetxebarria, M., Hodson, M.E., Schofield, P.F., Valsami-Jones, E., 2006. Use of bone meal amendments to immobilize $\mathrm{Pb}, \mathrm{Zn}$ and $\mathrm{Cd}$ in soil: a leaching column study. Environ. Pollut. 144, 816-825.

27. Sultana, M.Y., Akratos, C.S., Pavlou, S., Vayenas, D. V., 2014. Chromium removal in constructed wetlands; a review. Int. Biodeterior. Biodegr. 96, 181-190.

28. Sumner, M.E., Miller, W.P., 1996. Cation exchange capacity and exchange coefficients, Methods of Soil Analysis, Part 3: Chemical Methods. ASA and SSSA, Madison, Wisconsin, USA, pp. 1201-1229.

29. Száková, J., Tlustoš, P., Pavlíková, D., Hanč, A., Batysta, M., 2007. Effect of addition of ameliorative materials on the distribution of $\mathrm{As}, \mathrm{Cd}, \mathrm{Pb}$, and $\mathrm{Zn}$ in extractable soil fractions. Chem. Pap. 61 (4), 276-281.

30. Teng, Y., Feng, D., Wu, J., Rui, Z., Song, L., Wang, J., 2015. Distribution, bioavailability, and potential ecological risk of $\mathrm{Cu}, \mathrm{Pb}$, and $\mathrm{Zn}$ in soil in a potential groundwater source area. Environ. Monit. Assess. 187, 293.

31. Toth, G., Hermann, T., Da Silva, M.R., Montanarella, L., 2016. Heavy metals in agricultural soils of European Union with Implications for foed safety. Environ. Int. 88, 299-309.

32. Trakal, L., Neuberg, M., Tlustos, P., Szakova, J., Tejnecky, V., Drabek, O., 2011. Dolomite limestone application as a chemical immobilization of metal-contaminated soil. Plant Soil Environ. 57 (4), 173-179.

33. Usman, A., Kuzyakov, Y., Stahr, K., 2005. Effects of clay minerals on immobilization of heavy metals and microbial activity in a sewage sludge-contaminated soil. J. Soils Sediments 5 (4), 245-252.

34. Wang, H., Wang, X., Chen, J., Xia, P., Zhao. J., 2016. Recovery of nutrients from wastewater by $\mathrm{MgCl} 2$ modified zeolite and their reuse as an amendment of $\mathrm{Cu}$ and $\mathrm{Pb}$ immobilization in soil. RSC Adv. 6, 55809-55818.

35. Wuana, R.A., Okieimen, F.E., 2011. Heavy metals in contaminated soils: a review of sources, chemistry, risks and best available strategies for remediation. ISRN Ecol. 2011.

36. X. Querol, A. Alastuey, N. Moreno, E. AlvarezAyuso, A. García-Sánchez, J. Cama, C. Ayora, M. Simón, Immobilization of heavy metals in polluted soils by the addition of zeolite material synthesized from coal fly ash, Chemosphere 62 (2006) 171-180.

37. Zhou, Y., Tang, L., Zeng, G., Zhang, C., Zhang, Y., Xie, X., 2016. Current progress in biosensors for heavy metal ions based on DNAzymes/DNA molecules functionalized nanostructures: a review. Sensors Actuators B Chem. 233, 280-294. 